\section{A Mortal Complication in a Case with Mucopolysaccharidosis Type I Following Hematopoietic Stem Cell Transplantation: Pulmonary Haemorrhage}

\section{MPS Tip 1 Olgusunda Hematopoetik Kök Hücre Nakli Sonrası Mortal Komplikasyon: Pulmoner Hemoraji}

\section{Havva Yazıcı $\odot$ Ebru Canda ๑ Esra Er $\odot$ Barış Malbora ๑ Burcu Öztürk Hismi $\odot$ Hüseyin Onay $\odot$ Serap Aksoylar $\odot$ Sema Kalkan Uçar ๑ Ferda Özkinay $\odot$ Mahmut Çoker $\odot$}

\section{ABSTRACT}

Mucopolysaccharidosis type I (MPS I) is a lysosomal storage disease due to mutations within the gene IDUA encoding the " $\alpha$-L-iduronidase". The clinical manifestations concern multisystemic involvement. There are two disease modifying therapies, enzyme replacement therapy and haematopoietic stem cell transplantation (HSCT). Pulmonary haemorrhage (PH) is a rare complication of HSCT and the case was presented with the reason that the related reports were few in MPS I.

Keywords: MPS I, HSCT, pulmonary haemorrhage

\section{öz}

Mukopolisakkaridozis tip 1 (MPS 1) " $\alpha$-L-iduronidase" enzimini kodlayan IDUA geninde mutasyonlardan kaynaklanan bir lizozomal depo hastalığıdır. Multisistemik tutulumla karakterizedir. Enzim replasman tedavisi ve hematopoetik kök hücre nakli olmak üzere iki güncel tedavi yöntemi mevcuttur. Pulmoner hemoraji HSCT' nin nadir bir komplikasyaonu olup, MPS 1 hastalarında nadir olgu sunumları bildirilmiştir.

Anahtar kelimeler: MPS 1, HSCT, pulmoner hemoraji
Received: 16.09 .2020

Accepted: 21.11.2020

Published Online: 03.08.2021

Cite as: Yazıcı H, Canda E, Er E, et al. A mortal complication in a case with mucopolysaccharidosis type I following hematopoietic stem cell transplantation: Pulmonary haemorrhage. İzmir Dr. Behçet Uz Çocuk Hast. Dergisi. 2021;11(2):198-201.

Havva Yazıcı Ege Üniversitesi Tıp Fakültesi Pediatrik Metabolizma ve Beslenme Bilim Dalı, İzmir, Türkiye - havvaya@gmail.com ORCiD: 0000-0002-2564-7420

E. Canda 0000-0002-9175-1998 E. Er 0000-0001-8867-0508 S. Kalkan Uçar 0000-0001-9574-7841 F. Özkinay 0000-0001-7542-7787

M. Çoker 0000-0001-6494-9539 Ege Üniversitesi Tıp Fakültesi Pediatrik Metabolizma ve Beslenme Bilim Dalı, İzmir, Türkiye

B. Malbora 0000-0003-4838-814X Tepecik Eğitim Araştırma Hastanesi, Pediatrik Hematoloji Kliniği, İzmir, Türkiye

B. Öztürk Hismi 0000-0001-7146-0248 Tepecik Eğitim Araștırma Hastanesi, Pediatrik Metabolizma ve Beslenme Kliniği, Izmir, Türkiye

H. Onay 0000-0002-0584-8866 Ege Universitesi Tıp Fakültesi Tıbbi Genetik Anabilim Dalı, İmir, Türkiye

S. Aksoylar 0000-0002-8446-0834 Ege Üniversitesi Tıp Fakültesi Pediatrik Hematoloji Bilim Dalı Izmir, Türkiye 


\section{INTRODUCTION}

The mucopolysaccharidoses are a group of congenital metabolic diseases involving the intracellular deposition of various glycosaminoglycans (GAGs). MPS $I$ is caused by a deficiency of $\alpha$-L-iduronidase that leads to progressive accumulation of dermatan and heparan sulfate. Furthermore, these undegraded GAGs induce apoptosis in cells. Macrocephaly, coarse facies, hepatosplenomegaly, hernia, stiff joints, recurrent upper airway infections, otitis media, hearing loss, cardiac valve disease and/or cardiomyopathy, and neurologic impairment are the clinical features of MPS I. MPS I has three clinical subtypes based on clinical severity, respectively: a severe form - Hurler syndrome (MPS IH); an intermediate form - Hurler/Scheie syndrome (MPS IH/IS); and the mild form - Schie syndrome (MPS IS). p. Q70X and p.W402X variants severely disrupt protein/gene function; as such, their association with the severe phenotype has been demonstrated ${ }^{(1)}$.

MPS I brings about premature morbidity and mortality if left untreated, mainly due to cardiorespiratory issues.

Intravenous enzyme replacement therapy (ERT) and HSCT are the two major therapies available for the different clinical subtypes of MPS I. ERT (Laronidase - recombinant $\alpha$-L-iduronidase) has been available since 2003. ERT has been shown to improve somatic symptoms, but the results regarding cognitive function have been poor due to an inability to cross the blood-brain barrier ${ }^{(2)}$. HSCT was first reported in $1981^{(3)}$, although current HSCT treatments have been an option for those diagnosed with MPS IH before reaching two-and-a-half years of age. To the best of our knowledge, more than 500 transplants have been performed in sufferers of MPS I. Following transplantation, engrafted donor leukocytes act as a source of $\alpha$-L-iduronidase enzyme in the blood and central nervous system ${ }^{(1,4)}$. If initiated early, HSCT has been shown to preserve neurocognition and to achieve improved developmental outcomes, and is accordingly considered the gold standard of treatment for patients with MPS IH ${ }^{(1)}$. HSCT has enhanced neurocognitive and survival results with revisions in conditioning regimens, improvement in donor-recipient histocompatibility matching, and an expansion of donor sources. Mortality following HSCT can be divided into two categories: the first is transplant-related mortality, which develops within the first year after HSCT; the second involves mortality occurring after the first year. $\mathrm{PH}$ is a rare complication of HSCT, and represents one of the transplant-related causes of mortality ${ }^{(5)}$.

\section{CASE REPORT}

The infant was born to healthy consanguineous parents. Family history was non-contributory. A female new-born with a gestational age of 39 weeks and 4 days, and a birth weight of $2800 \mathrm{~g}$, was born following a cesarean section to a 22-year-old primigravida mother whose pregnancy was followed. The patient had a large anterior fontanelle, coarse facies, macrocephaly, organomegaly, and a large Mongolian spot on her initial examination.

Laboratory investigations were notable for high urine GAGs (515 mg/g creatinine, N: <140) and low $\alpha$-L-iduronidase enzyme activity in dried blood $(0.42$ $\mathrm{nmol} / \mathrm{mL} / \mathrm{h}, \mathrm{N}: 2.3-10)$. She was diagnosed on the basis of enzymatic testing with MPS IH. Later, IDUA gene analysis showed a homozygous nonsense mutation of p.Q70X (c.208C >T).

At the 12th month of life, the patient was diagnosed with MPS I, and was started on a treatment with $0.58 \mathrm{mg} / \mathrm{kg} /$ dose intravenous ERT with Laronidase once a week, with continued treatment following HSCT. BMT was performed at the age of 19 months with a 5/6 HLA match, unrelated cord-blood donor. She received a preparatory treatment with fludarabine, busulfan, and melphalan containing myeloablative chemotherapy. She received graftversus-host-disease (GVHD) prophylaxis with cyclosporine, anti-thymocyte globulin, and prednisolone. Enzyme activity returned to near normal (1.9 $\mathrm{nmol} / \mathrm{mL} / \mathrm{h}, \mathrm{N}: 2.3-10)$ on day +31 . She showed engrafting of white cells and platelets on day +12 ; and chimerism studies on day +44 confirmed $100 \%$ donor engraftment. The patient had grade-II GVHD on day +41 . On day +53 , the patient had been afe- 


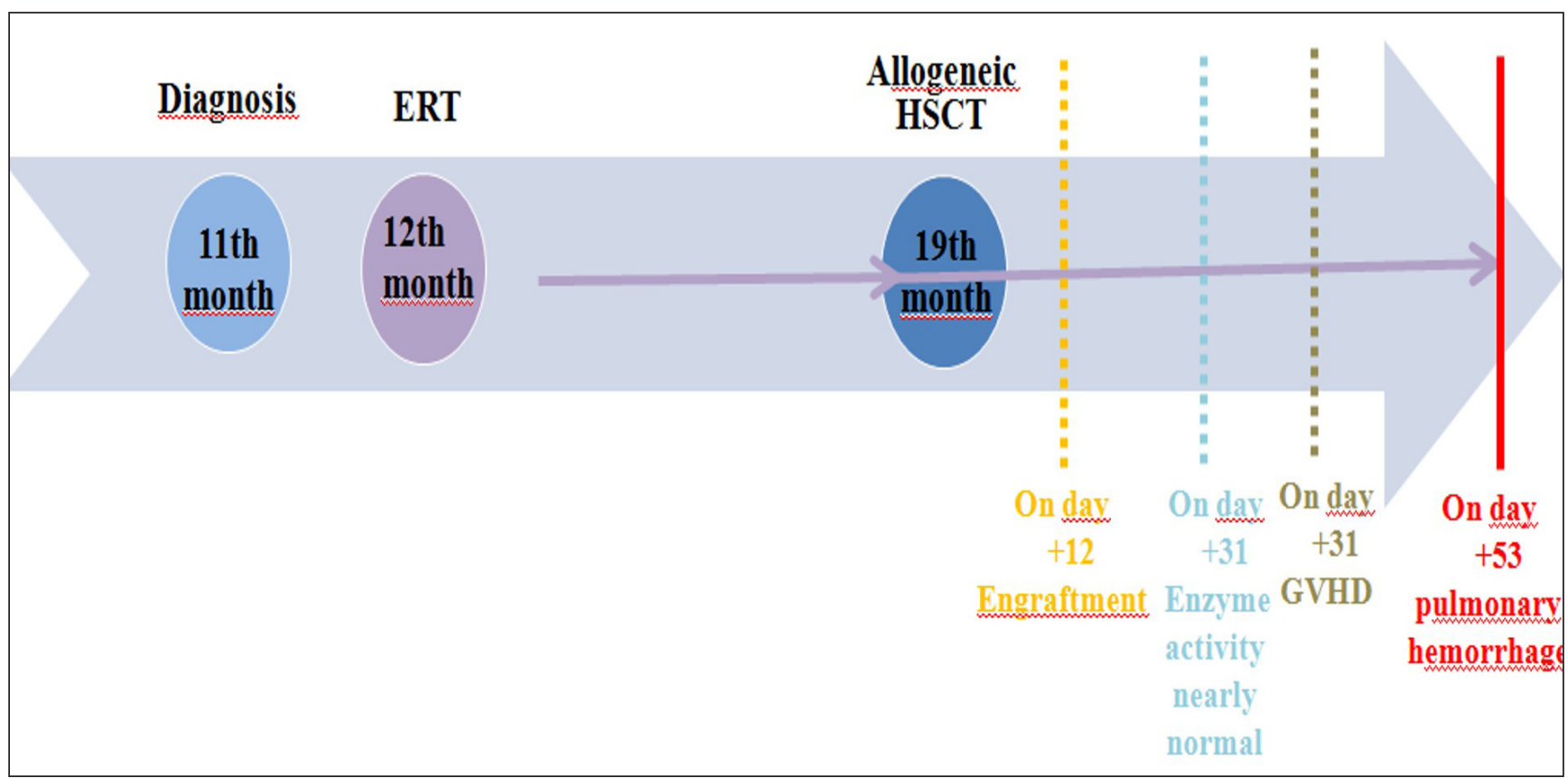

Figure 1.

brile for the previous seven days, and presented with sudden-onset tachypnoea, dyspnea, haematemesis, and unexplained severe oxygen desaturation rapidly followed by cardiorespiratory arrest and death. On day +52 , her hemoglobin, white blood cells, and platelets were $8.5 \mathrm{~g} / \mathrm{dl} 18.1 \times 103 / \mu \mathrm{L}$ and $30 \times 103 / \mu \mathrm{L}$ respectively. The family did not allow a post-mortem histopathological examination to be carried out.

\section{DISCUSSION}

Untreated Hurler patients would likely die in the first decade of life, but HSCT and ERT are two treatments that slow progression and provide benefit. HSCT has been shown to increase survival, and the best results have been achieved when HSCT is performed before 2.5 years of age and within six months of diagnosis. Hematopoietic stem cell transplantation has been used since 1981 in the treatment of MPS I. In the case we have presented, HSCT was performed at 19 months and seven months after diagnosis. IDUA gene analysis revealed a homozygous mutation for p.Q70X. This nonsense mutation is notably common, and is known to be related to the Hurler phenotype due to a complete lack of residual enzymatic activity. Enzyme replacement therapy with Laronidase has been available since 2003. ERT should be initiated at the first opportunity and a decision is usually made to start ERT on diagnosis. However, the age of diagnosis and initiation of treatment varies depending on whether the new-bornscreening program of any given country includes MPS type-I or not. The new-born-screening program in Turkey does not include MPS type-I. Pre-HSCT and peri-HSCT administration of ERT should be considered as a supportive/adjuvant treatment in addition to HSCT for patients with MPS IH, and we also continued pre-HSCT and peri-HSCT ${ }^{(1,6)}$. In the literature, the age at onset of ERT in MPS type-I cases who underwent HSCT in whom PH had previously been reported was not specified ${ }^{(4,7,8)}$.

We have described $\mathrm{PH}$ as a lethal complication in the patient with MPS IH following unrelated donor cord-blood transplantation. The incidence of death from $\mathrm{PH}$ was revealed to be highest within the first year following HSCT in patients with MPS I. Patients with inherited metabolic storage diseases are at a higher risk of developing pulmonary complications following HSCT. The pathogenesis of pulmonary complications in patients undergoing HSCT is unclear. Several studies have shown that the local proinflammatory cytokine cascade produced by alveolar mac- 
H. Yazıcı et al. A Mortal Complication in a Case with Mucopolysaccharidosis Type I Following Hematopoietic Stem Cell Transplantation:

Pulmonary Haemorrhage

rophages and donor-derived cytokines plays a crucial role in these complications developing following HSCT ${ }^{(7,8)}$.

\section{CONCLUSIONS}

$\mathrm{PH}$ is rare following autologous and allogeneic BMT. The etiology of $\mathrm{PH}$ post-BMT is unclear, but is believed to be multifactorial. There is limited experience described in the literature in relation to $\mathrm{PH}$ in patients with MPS I treated with bone marrow transplantation. Therefore, we would like to highlight this case of PH in MPS I following HSCT.

Conflict of Interest: The authors declared that this study received no financial support.

Informed Consent: Informed consent was obtained from the parents of the patient for publication of this case.

\section{REFERENCES}

1. Parenti $G$ and Wraith EJ. The Mucopolysaccharidoses. In: Blau N, Duran M, Gibson KM, Dionisi-Vici C (eds) Physician's Guide to the Diagnosis, Treatment, and Follow-Up of Inherited Metabolic Diseases, Springer, Heidelberg, New York, Dordrecht, London, 2014; pp 449-464.

https://doi.org/10.1007/978-3-642-40337-8_27
2. Hobbs JR, et al. Reversal of clinical features of Hurler's disease and biochemical improvement after treatment by bone-marrow transplantation. The Lancet 1981;318(8249): 709-12.

https://doi.org/10.1016/S0140-6736(81)91046-1

3. Boelens JJ, et al. Outcomes of transplantation using various hematopoietic cell sources in children with Hurler syndrome after myeloablative conditioning. Blood (2013): blood-2012.

4. Rodgers NJ, et al. Mortality after hematopoietic stem cell transplantation for severe mucopolysaccharidosis type I: the 30-year University of Minnesota experience. Journal of Inherited Metabolic Disease 2017;40(2):271-80. https://doi.org/10.1007/s10545-016-0006-2

5. Conner T, Cook F, Fernandez V, Rascati K, Rangel-Miller V. An online survey on burden of illness among families with poststem cell transplant mucopolysaccharidosis type I children in the United States. Orphanet Journal of Rare Diseases, 2019;14(1):48.

https://doi.org/10.1186/s13023-019-1027-3

6. Kunin-Batson AS, et al. Long-term cognitive and functional outcomes in children with mucopolysaccharidosis (MPS)-IH (Hurler syndrome) treated with hematopoietic cell transplantation. JIMD Reports, Volume 29. Springer, Berlin, Heidelberg, 2015;95-102.

https://doi.org/10.1007/8904_2015_521

7. Kharbanda S, et al. Inflammatory cytokines and the development of pulmonary complications after allogeneic hematopoietic cell transplantation in patients with inherited metabolic storage disorders. Biology of Blood and Marrow Transplantation 2006;12(4):430-7. https://doi.org/10.1016/j.bbmt.2005.12.026

8. Gassas A, et al. Life-threatening pulmonary hemorrhages post bone marrow transplantation in Hurler syndrome. Report of three cases and review of the literature. Bone Marrow Transplantation 2003;32(2):213.

https://doi.org/10.1038/sj.bmt.1704115 